\title{
The Analysis of Mastering of Concepts and Misconceptions in Elementary Teacher Education Students
}

Maria Melani Ika Susanti ${ }^{1 *}$

${ }^{1}$ Elementary Teacher Education Study Program, Sanata Dharma University

e-mail: maria.melani.ika@gmail.com ${ }^{1}$

\begin{abstract}
This study aims to analyze the mastery of the concepts and misconceptions of heat material in students of the Elementary Teacher Education Study Program. This type of research is descriptive quantitative. The research subjects were 47 students. Collecting data in this study through online test evaluation with a google form. The results of this study were the mastery of the concept and misconceptions of heat material in the Elementary Teacher Education Study Program students from the 10 questions given, there were 5 questions that had a concept mastery percentage of more than $50 \%$, while the other 5 questions students experienced misconceptions with a percentage of more than $50 \%$. This misconception will have implications for the mastery of student concepts at the next stage and especially for students who become learning subjects when students become teachers.
\end{abstract}

Keywords : mastering of concepts, misconceptions

\section{Introduction}

Science learning material includes components of Physics, Biology, and Chemistry, but in this study examines one of the content of science learning, namely Physics. Learning Science makes students (students) have more direct experience in combining and creating solution problems and carrying out scientific investigations (Martinez, 2017). Science can be defined as the study of the causes and effects of events that exist in nature (Wisudawati \& Eka, 2014). Science is a concept and conceptual scheme that is related to one another, and which grows as a result of experimentation and observation, and is useful for further observation and experimentation (Samatowa, 2006). In addition, science is a human effort which includes mental aspects, skills, and strategies for manipulating and calculating which can be re-tested, and based on curiosity, determination, and perseverance made by individuals to reveal the secrets of nature (Candra, 2006). Based on the explanation of the three experts above, it can be formulated that science is a science that studies the cause and effect of events that exist in nature as a result of experimentation and observation which includes mental aspects, skills, and strategies for manipulating and calculating which can be retested and based on by an attitude of curiosity, determination, and perseverance carried out by the individual.

In physics learning material, there are concepts that are prone to misconceptions. Alternative concepts or misconceptions occur in all fields of physics (Suparno, 2005). Alternative concepts or misconceptions are different from concepts. The concept is a collection of stimulus that have the same characteristics (Depdikbud, 1999), while alternative concepts or misconceptions are concepts that are incompatible with the scientific understanding or understanding accepted by experts in that field (Suparno, 2005). One of the physical materials related to everyday life is heat. Heat is one of the materials found in physics. Some of the key concepts discussed in heat material include changes in the shape of objects, the concept of heat, specific heat of substances, heat of melting substances, heat of substance vapors, and implementation of heat in everyday life. Heat is heat energy that is owned by a substance (Muhsin, 2019). Heat and temperature cannot be separated (Nursyamsi, Sujiono, \& Yani, 2018). Heat causes the temperature of an object to increase. Although different meanings,

\footnotetext{
${ }^{*}$ Corresponding author.
}

Received 15 July 2020; Accepted 13 September 2020; Available online 01 March 2021 (c) 2020 JPI. All Rights Reserved 
temperature is the level of heat or coldness of an object, while heat is a form of energy. Temperature and heat cannot be separated.

One of the efforts to identify misconceptions and conceptual mastery is through evaluation. Evaluation is one of a series of activities to improve the quality, performance or productivity of an institution in implementing its program (Mardapi, 2017). The evaluation in this study used multiple choice questions given during the Mid-Semester Examination of the 2019/2020 academic year. Evaluation questions are carried out by filling in the google form. The test instrument was tested on 2nd semester students of the Class A Elementary Teacher Education Study Program, Sanata Dharma University participants in the Elementary School Physics course. The focus of the evaluation is on heat material. The study was conducted to determine the mastery of the concepts and misconceptions of heat material in students of the Elementary Teacher Education Study Program. Researchers hope that after knowing the students' mastery of concepts, further steps can be taken as material for improvement to reduce misconceptions that occur.

Student mastery of the materials described above is one indicator of student success in lectures. One of the efforts made to determine the achievement of learning science in heat material is conducting an evaluation. Evaluation is one of a series of activities to improve the quality, performance or productivity of an institution in implementing its program (Mardapi, 2017). In line with the previous opinion that evaluation is a process or activity of selecting, collecting, analyzing, and presenting information that can be used as a basis for decision making and further programming (Widoyoko, 2009). Then, Basuki \& Hariyanto (2014) defines evaluation as a systematic process of collection, analysis, and interpretation to determine the extent to which students achieve learning objectives as stated in the curriculum. In general, evaluation is used to assess an educational program, curriculum, and / or organizational situation. In addition, evaluation is also used for the purposes of research and / or development of educational programs, curricula, teaching materials, and so on (Sani, 2016). It can be formulated that evaluation is an activity of collecting, analyzing, and presenting information on programs that have been implemented for later decisions to be made in preparing and implementing the next program. Through evaluation, evaluators will get information about what has been achieved and which has not, and then this information will be used to improve a program (Mardapi, 2017). By doing so, it is hoped that the next program will have better results than the previous one.

The evaluation chosen in this study was a test. Mardapi (2017) defines the test as one of the instruments used to take measurements. The test chosen is an objective multiple choice test. Objective test as a form of test that contains possible answers or responses that have been provided by item compilers and participants only choose alternative answers (Widoyoko, 2009). Multiple choice test consists of a description or notification of an incomplete meaning. To complete it, you have to choose one of several possible answers that have been provided. The multiple choice test also consists of a description section and a section on possible answers or alternatives. The possible answers consist of one correct answer, namely the answer key and several trickster (Arikunto, 2018).

The test results can indicate a person's mastery of concepts. The concept is a product of a scientific process. The concept is defined as a collection of stimuli that have the same characteristics (Depdikbud, 1999). Based on these descriptions, to master the concept one must be able to distinguish one thing from another. Another explanation was put forward by Wisudawati \& Eka (2014) that the concept is the result of the thought of a person or group of people who are stated in the definition so as to produce knowledge products including principles, laws, and theories. Concept is an ability that enables humans to do something (Depdikbud, 1991). This can be interpreted that if you master the concept of humans, you cannot do anything about it and it might interfere with their survival. Based on the expert's explanation above, the researcher formulates that the concept is the result of thoughts that have the same characteristics that are stated in the definition and allow humans to do something.

In general, misconceptions can be divided into two forms, namely the incomplete initial concept (preconception) and the initial concept which is completely wrong (Suparno, 2008). 
This presentation is in line with previous research that student preconceptions greatly influence misconceptions (Armen \& Helendra, 2017; Kuczmann, 2017; Ramadhani, Hasanuddin, \& Asiah, 2016; Sarlina, 2015). Preconceptions need to be considered before implementing learning. Preconceptions are experiences of everyday life which become students' initial knowledge. Misconceptions are concepts that are incompatible with the scientific understanding or understanding accepted by experts in that field (Suparno, 2005). Misconception is an initial concept that is incompatible with experts (Wisudawati \& Eka, 2014). Based on the explanation from the experts above, the researcher formulates that misconception is a concept that is incompatible with the expert.

This study aims to analyze the mastery of the concepts and misconceptions of heat material in students of the Elementary Teacher Education Study Program.

\section{Method}

This research uses descriptive quantitative research. Descriptive research is research that seeks to describe the current problem solving based on data (Narbuko \& Abu, 2013). Quantitative research uses data that is calculated using numbers. The research was conducted in March 2020. The subjects of this study were the second semester students of class A Elementary Teacher Education Study Program, Sanata Dharma University, totaling 47 students. Collecting data in this study by providing an evaluation in the form of test questions during the Mid-Semester Examination to students. The form of the test given is in the form of multiple choices, and is done online via google form. Evaluation is focused on heat material. The following is a table of indicators about the heat material in this study.

Table 1. Indicator of Matter of Heat Matter

\begin{tabular}{clc}
\hline No. & \multicolumn{1}{c}{ Indicator } & $\begin{array}{c}\text { Item } \\
\text { Number }\end{array}$ \\
\hline 1 & Analyze the concept of change in form & 1,9 \\
2 & Resolving problems about transformation & 4,6 \\
3 & Analyzing the application of the concept of heat in the phenomena that & $2,3,10$ \\
& occur & 5 \\
4 & Solve problems about the concept of heat & 7,8 \\
5 & Analyze the implementation of heat expansion in everyday life & 7 \\
\hline
\end{tabular}

Each number is assigned a score of 1 if true and a score of 0 if it is false. Quantitative data analysis techniques were carried out to determine the mastery of the physics science concept of Elementary Teacher Education Study Program students on heat material.

\section{Results and Discussion Results}

There are five indicators of heat material achievement in this study as presented in table 1, namely: The first indicator: analyzing the concept of change in form is translated into two questions, namely item numbers 1 and 9 . The second indicator: solving problems about change in form is translated into two questions, namely item numbers 4 and 6 . The third indicator: analyzing the application of the concept of heat in the phenomenon that occurs is translated into three questions, namely item numbers 2, 3, and 10. Fourth indicator: solving problems about the concept of heat is translated into one question, namely item number 5 . And indicators Fifth: to analyze the implementation of heat expansion in everyday life, break down into two questions, namely item numbers 7 and 8 . The percentage of answers to each item based on the indicators can be seen in the following table. 
Table 2 Percentage of Answers for Each Question Item

\begin{tabular}{lccc}
\hline \multirow{2}{*}{ Indicator } & \multirow{2}{*}{ Item No } & \multicolumn{2}{c}{ Percentage (\%) } \\
\cline { 3 - 4 } & & Right & Wrong \\
\hline Analyze the concept of change in form & 1 & 53.19 & 46.81 \\
& 9 & 46.81 & 53.19 \\
Resolving problems about transformation & Average & $\mathbf{5 0}$ & $\mathbf{5 0}$ \\
& 4 & 65.96 & 34.04 \\
Analyzing the application of the concept of heat in the & 6 & 44.68 & 55.32 \\
phenomena that occur & Average & $\mathbf{5 5 . 3 2}$ & $\mathbf{4 4 . 6 8}$ \\
& 3 & 29.79 & 70.21 \\
Solve problems about the concept of heat & 10 & 63.83 & 36.17 \\
& Average & $\mathbf{3 6 . 8 8}$ & $\mathbf{6 3 . 1 2}$ \\
Analyze the implementation of heat expansion in & 5 & 87.23 & 12.77 \\
everyday life & Average & $\mathbf{8 7 . 2 3}$ & $\mathbf{1 2 . 7 7}$ \\
& 7 & 31.91 & 68.09 \\
& 8 & 82.98 & 17.02 \\
& Average & $\mathbf{5 7 . 4 4}$ & $\mathbf{4 2 . 5 6}$ \\
\hline
\end{tabular}

Based on table 2, it is found that misconceptions are still found in each indicator. The biggest misconception of $63.12 \%$ occurred in the third indicator, namely analyzing the application of the concept of heat in the phenomena that occurred. Then the first indicator analyzes the concept of change in form by $50 \%$, the second indicator resolves problems about change in form of $44.68 \%$, the fifth indicator analyzes the implementation of heat expansion in everyday life by $42.56 \%$, and finally the fourth indicator resolves problems regarding the concept of heat. amounted to $12.77 \%$.

The description of the misconceptions experienced by students on each indicator and item is as follows. Indicators analyze the concept of change in form in questions 1 and 9 . In question number 1,25 students $(53.19 \%)$ gave the correct answer, which means that the student mastered the concept that no matter how much hot water will not affect the melting speed of butter, because the temperature of hot water in any amount is always constant. Meanwhile, 22 other students (46.81\%) answered incorrectly, which means that the student had a misconception. Students do not fully understand the concept of the types of heat conductor and the effect of the type of heat conductor on the melting speed and melting time of the material applied to the heat conductor. In question number 9 as many as 22 students $(46.81 \%)$ answered correctly, which means that the student mastered the concept that each stage in the process of change in form does not always require a change in temperature, such as fusion, evaporation, and other changes in form only require heat and take place. at a constant temperature, meaning that the process does not change in temperature. The misconception was experienced by 25 students (53.19\%), students were not yet able to fully interpret the graph displayed from a process of melting ice with a temperature of -200C into water at temperatures above $1000 \mathrm{C}$.

In question number 4 as many as 31 students (65.96\%) answered correctly, students could solve questions about changing form and were correct in choosing formulas. Students fully understand that in the melting process, the heat required is only the heat of melting ice, not other types of heat. Meanwhile, 16 students (34.04\%) still experienced misconceptions, some of whom were still unable to distinguish between the concepts of specific heat and melted heat to solve problems regarding form change. Inaccuracy in selecting specific heat will have an impact on the results of heat calculations Problem number 6 is a reverse analysis problem. The amount of heat has been presented at the beginning, but students are asked to analyze the process that occurs in it gradually. As many as 21 students (44.68\%) answered correctly, meaning that students were able to think in reverse by breaking down the heat 
needed at each stage of change in form. Meanwhile 26 students $(55.32 \%)$ were still unable to solve these questions.

The indicator analyzes the application of the concept of heat in the phenomena that occur in questions 2,3 , and 10 . A total of 14 students (29.79\%) have understood the concept that heat in a system can be maintained through a treatment, for example for the case above so that our bodies stay warm and don't feel the cold outside, need to wear warm clothes, this principle is also used in the case above. hot water flask. Meanwhile 33 students $(70.21 \%)$ have a concept that is still wrong, including the understanding that heat transfers from a cold environment to our hot body. The air temperature outside is indeed lower than body temperature, but in this matter it is more on the application of heat so that students have not yet reached an analysis of why the body remains warm when wearing warm clothes even in cold areas.

On item 3, as many as 30 students (63.83\%) answered correctly. Plastics have a specific heat greater than stainless steel. The greater the specific heat of an object, the less the ability of the object to absorb or release heat. This means that a plastic spoon will have a small ability to release heat, the heat in it will last longer. In contrast, stainless steel has a greater ability to release heat, so it cools faster at low temperatures (cold water). 17 students $(36.17 \%)$ still have the wrong concept of specific heat. Some argue that the specific heat of each object is the same, some argue that plastic spoons are cooler than stainless steel, and some argue that the temperature of the water will affect the plastic spoons, even though plastic is an insulator so it doesn't easily conduct heat.

In question number 10 there were only 8 students (17.02\%) who had the right concept. Meanwhile, 39 students (82.98\%) still do not have the right concept. In the above case, the outer wall of the glass containing iced tea appears as water droplets because the air around the glass (which is hotter) releases heat so that the air turns into water which sticks to the glass wall. The misconception includes understanding the concept that water seeps through the pores of the glass wall. This concept is incorrect because glass is not porous. The next misconception is that ice releases heat. This concept is incorrect because substances that release heat are substances that have a higher heat (in this case, the temperature around the glass). The third misconception is that condensation occurs because the air in the glass releases heat. The right concept is that the air outside the glass releases heat.

The indicator for solving the problem regarding the concept of heat is in question number 5 . In question number 5 as many as 41 students (87.23\%) answered correctly, students can use the correct equation to solve this problem. Errors generally occur in temperature changes that occur in the process. Many do not understand that a change in temperature is the difference between the final temperature and the initial temperature. 6 students (12.77\%) still experienced this misconception.

Indicators analyzing the implementation of heat expansion in everyday life are found in questions number 7 and 8 . In question number 7, 15 students (31.91\%) answered correctly, meaning that the students understood the concept of bimetal expansion. If the bimetal strip expands it will result in a curved strip according to the metal expansion coefficient. If the top layer has a smaller metal expansion coefficient, the chip will curve upwards and is no longer connected to the electrical circuit. This event caused the current to no longer flow and the lights went out. As many as 32 students (68.09\%) still experienced misconceptions. Students did not understand the concept of expansion in the bimetal strip and its consequences on the electrical circuit and the components in the circuit. This problem is an example of real activities that occur in everyday life when using automatic electric irons. In question number 8, 39 $(82.98 \%)$ answered correctly, meaning that students already understand the concept of expansion and the working principle of the thermometer. When the thermometer is put in hot water, the scale on the thermometer will increase due to the expansion of the liquid in the capillary tube. Eight other students $(17.02 \%)$ still answered incorrectly, students understood that the scale on the thermometer would decrease due to the expansion of the liquid in the capillary tube, the scale on the thermometer would increase because hot water absorbed heat, and the scale on the thermometer would increase due to shrinkage of the liquid in the pipe. 
The results of the analysis show that on the indicators of solving problems about the concept of heat, students already have mastery of the right concept, as evidenced by the achievement of $87.23 \%$. For indicators to analyze the implementation of heat expansion in everyday life, the students' mastery of concepts was $57.44 \%$ and indicators of solving problems about change in form, the achievement of concept mastery was $55.32 \%$.

\section{Discussion}

The highest misconception occurred in the indicator analyzing the application of the concept of heat in the phenomenon that occurred at $63.12 \%$. The questions presented in this indicator are more contextual and real in everyday life, but it is unfortunate that students still experience misconceptions. These findings are similar to research conducted by (Setyadi \& Komalasari, 2012; Wahyudi \& Maharta, 2013; Syahrul \& Setyarsih, 2015; Ramadhan, Sunardi, \& Kurniati, 2017; Nurhidayatullah \& Prodjosantoso, 2018; Febrianti, Akhsan, Muslim, 2019) that misconceptions are still dominant, meanwhile students' conceptual mastery is still in the low category. The low concept mastery according to (Karim, 2011) is determined by the learning process that is applied. The lecture process that optimally facilitates students is assumed to result in complete mastery of concepts. Explanation of concepts using simple terms by the lecturer and easy to understand by students will affect the integrity of the concepts captured by students. Examples of real cases that are very close to the daily lives of students (contextual) will be able to help students understand the concepts being discussed. This is in line with the results of research conducted by (Jarmita, 2013; Efwinda \& Sopandi, 2016; Arisanti, Sopandi, \& Widodo, 2016; Astuti, 2017) which reveal that low concept mastery is caused by a lack of ability to grasp understanding such as presenting it in a form that is easy to understand and can not apply it in everyday life, causing misconceptions.

Students who experience misconceptions are different from students who do not understand the concept (Wulandari, Mulyani, \& Utami., 2019). Students who experience misconceptions tend to be sure of their understanding even though it is actually not in accordance with the correct concept, while students who do not understand the concept really do not have knowledge related to the concept. The causes of misconceptions in general are from students / students, lecturers / teachers, textbooks, context, and teaching methods (Suparno, 2005). The causes of misconceptions originating from students / learners include preconceptions, abilities, stages of development, interests, ways of thinking, and friends. The causes of misconceptions originating from lecturers / teachers are in the form of lack of mastery of the material, inaccurate teaching methods, and poor attitudes and relationships with students / students. The causes of misconceptions from the textbook are due to incorrect explanations. Causes of misconceptions in context such as culture, religion, and language also influence misconceptions. While the causes of misconceptions in teaching methods that emphasize one-sided truth often lead to misunderstandings of students / learners.

Ways to overcome misconceptions, namely: finding or uncovering misconceptions made by students / students; trying to find the causes of these misconceptions; and looking for appropriate treatment to overcome them (Suparno, 2005). Finding out the causes of misconceptions is very important before finding out how to overcome them. Educators must be creative and willing to find solutions that suit the problems and situations. Several previous studies have looked for causes of misconceptions (Mentari, Suardana, \& Subagia, 2014; Medina, 2015; Faizah, 2016; Sholihat, Samsudin, \& Nugraha, 2017; Resbiantoro \& Nugraha, 2017). According those several studies, the causative factors Other misconceptions such as educators provide incomplete concepts.

Misconceptions can only be accepted in certain cases and do not apply to other cases (Septiana, Zulfiani, \& Noor, 2014; Laksana, 2016; Wahyuningsih, 2016; Islami et al, 2018). Likewise, the results of this study are only limited to the scope of the sample of this study. Misconceptions that occur in Elementary Teacher Education Study Program students of Sanata Dharma University on each indicator, especially indicators analyze the application of the concept of heat in phenomena that occur which are more than $50 \%$, need to be further explored the causes of student misconceptions whether the cause comes from internal students, from lecturers when teaching material, from textbooks what is learned, from the 
surrounding context, or from the teaching method chosen by the lecturer which causes misconceptions. If misconceptions occur in students / learners, it tends to be difficult to change and will affect the next teaching and learning process (Laksana, 2016).

Based on the results of this study, it is necessary to follow up to find out the most appropriate causes and solutions to overcome the misconceptions that occur. Misconceptions that occur in students tend to be difficult to change and will affect the next teaching and learning process (Laksana, 2016). Justification of misconceptions needs to be done at all levels of education. Evaluation can be one way to determine student mastery of concepts and misconceptions.

\section{Conclusions and Suggestions}

Based on the results of the analysis and discussion of the conclusions of this study, namely the mastery of the concepts and misconceptions of heat material in the Elementary Teacher Education Study Program students from the 10 questions tested which represented the five indicators, misconceptions were still experienced by students. This misconception occurs in indicators of analyzing the concept of change in form, solving problems about change in form, analyzing the application of the concept of heat in the phenomena that occur, solving problems about the concept of heat, and analyzing the implementation of heat expansion in everyday life.

\section{References}

Arikunto, S. (2018). Basics of educational evaluation. PT Bumi Askara.

Arisanti, W.O.L., Sopandi, W., \& Widodo, A. (2016). Analysis of the mastery of concepts and creative thinking skills of elementary students through project based learning. EduHumaniora Jurnal Pendidikan Dasar, 8(1), 81-95. https://doi.org/10.17509/eh.v8i1.5125.

Astuti, L.S. (2017). Mastery of science concepts in terms of self-concept and student interest in learning. Formatif: Jurnal IImiah Pendidikan MIPA, 7(1), 40-48. https://doi.org/10.30998/formatif.v7i1.1293.

Aulia, S., Diana, N., \& Yuberti. (2018). Analysis of junior high school students' misconceptions on physics material. Indonesian Journal of Science and Mathematics Education, 1(2), 155-161. https://doi.org/10.24042/ijsme.v1i2.3516.

Basuki, I., \& Hariyanto. (2014). Learning assessment. PT Remaja Rosdakarya.

Candra, D. T. (2006). Learn science quality standards. Pelangi.

Depdikbud. (1999). The science concept was selected in elementary school, frequently encountered errors and suggestions for their solutions. Departemen Pendidikan dan Kebudayaan.

Efwinda, S., \& Sopandi, W. (2016). Increasing students' mastery of concepts through problembased integrated science learning assisted by mind maps. EduSains, 8(1), 27-35. https://doi.org/10.15408/es.v8i1.1580.

Faizah, K. (2016). Misconceptions in science learning. Jurnal Darussalam: Jurnal Pendidikan, Komunikasi dan Pemikiran Hukum Islam, 8(1), 115-128. https://doi.org/10.30739/darussalam.v8i1.10.

Febrianti, J., Akhsan, H., \& Muslim, M. (2019). Analysis of temperature and heat misconceptions in students of SMA Negeri 3 Tanjung Raja. Jurnal Inovasi dan Pembelajaran Fisika, 6(1), 90-102). https://doi.org/10.36706/jipf.v6i1.7819.

Gumilar, S. (2016). Analysis of misconceptions of style concepts using a certainty of response index (CRI). Gravity, 2(1), 59-71. http://dx.doi.org/10.30870/gravity.v2i1.924.

Islami, D., Munawaroh, F., \& Hadi, W.P. (2018). Analysis of student misconceptions in science subjects static electricity material using a four tier test. Science Educational National Conference, 71-77. https://journal.trunojoyo.ac.id/nser/article/view/4794.

Jannah, A.N., Yuliati, L., \& Parno. (2016). Mastery of concepts and students' ability to ask questions on Newton's law material through inquiry lesson learning with the LBQ strategy. Jurnal Pendidikan, 1(3), 209-420. http://dx.doi.org/10.17977/jp.v1i3.6167. 
Jarmita, N. (2013). Analysis mastery of concepts and difficulties in mathematics material in an effort to increase the competence of PGMI students. EduSains, 1(2). https://doi.org/10.23971/eds.v1i2.10.

Karim, A. (2011). The application of the guided discovery method in mathematics learning to improve the mastery of concepts and critical thinking skills of elementary school students. Jurnal UPI edisi khusus, (1). http://jurnal.upi.edu/file/3-Asrul_Karim.pdf.

Kuczmann, I. (2017). The structure of knowledge and students' misconceptions in physics. AIP Conference Proceedings 1916 (December). https://doi.org/10.1063/1.5017454.

Kuslan, L.I., \& Stone, A.H. (1969). Teaching children science: an inquiry approach. Wadsworth Publising Company.

Laksana, D.N.L. (2013). The profile of the understanding of the science concept of elementary school class teachers in Ngada Regency. Jurnal IImiah Pendidikan, 1(1), 27-38. http://ejournal.citrabakti.ac.id/index.php/jipcb/article/view/37.

Laksana, D.N.L. (2016). Misconceptions in elementary school science material. Jurnal Pendidikan Indonesia, 5(2), 166-175. https://doi.org/10.23887/jpi-undiksha.v5i2.8588.

Liu, G., \& Fang, N. (2016). Student misconceptions about force and acceleration in physics and engineering mechanics education. International Journal of Engineering Education, 32(1), 19-29.

Maesyarah, Jufri, A.W., \& Kusmiyati. (2015). Analysis the mastery of biological concepts and misconceptions using modification techniques. Jurnal Pijar MIPA, 10(1), 1-6. https://doi.org/10.29303/jpm.v10i1.8.

Mardapi, D. (2017) Measurement, assessment, and evaluation of education. Parama Publishing.

Martinez, J.E. (2017). The search for method in STEAM education. New York Institute of Tecnology.

Medina, P. (2015). Analysis of class X students' misconceptions on electrolyte and nonelectrolyte solution material as well as oxidation and reduction reactions in chemistry learning at SMAN Kota Padang. Jurnal Pendidikan dan Teknologi Informasi, 2(1), 7384. http://lppm.upiyptk.ac.id/pti/index.php/pti/article/view/55/0.

Mentari, L., Suardana, I.N., \& Subagia, I.W. Analysis of high school students' misconceptions on chemistry learning for buffer solution material. Kimia Visvitali, 2(1), 76-87. http://dx.doi.org/10.23887/jjpk.v1i1.3975.

Muhsin. (2019). Application of the talking stick learning model to improve positive attitudes and learning achievement in science subject heat in students. Jurnal Pendidikan Fisika, 7(1), 32-48. https://doi.org/10.26618/jpf.v7i1.1685.

Narbuko, C. \& Abu, A. (2013). Research methodology. PT Bumi Askara.

Nurhidayatullah, N., \& Prodjosantoso, A.K. (2018). Misconception of buffer solution material. Jurnal Inovasi Pendidikan IPA, 4(1), 41-51. https://doi.org/10.21831/jipi.v4i1.10029.

Nursyamsi, Sujiono, E.H., \& Yani, A. (2018). Identification misconceptions of temperature and heat physics material using cri (certainty of response index) in class XI mia students of SMA Negeri 8 Bulukomba academic year 2015/2016. Jurnal Sains dan Pendidikan Fisika, 14(2), 44-54. https://ojs.unm.ac.id/JSdPF/article/view/10811.

Ramadhan, M., Sunardi, \& Kurniati, W. (2017). Analysis of students' misconceptions in solving PISA standard math problems using a certainty of response index (CRI). Jurnal Matematika dan Pendidikan Matematika, 8(1), 145-153. https://jurnal.unej.ac.id/index.php/kadikma/article/view/5276.

Ramadhani, R., Hasanuddin, \& Asiah, M.D. (2016). Identification of student misconceptions on the concept of the human reproductive system in class XI IPA SMA Unggul Ali Hasjmy Aceh Besar District. Jurnal IImiah Mahasiswa Pendidikan Biologi, 1. http://jim.unsyiah.ac.id/pendidikan-biologi/article/view/373.

Resbiantoro, G., \& Nugraha, A.W. (2017). Student misconceptions on the basic concepts of style and motion for elementary schools. Jurnal Pendidikan Sains, 5(2), 80-87. https://doi.org/10.26714/jps.5.2.2017.80-87.

Samatowa, U. (2006). How to teach science in elementary school. Depdiknas.

Sani, R.A. (2016). Authentic assessment. PT Bumi Askara. 
Sarlina. (2015). Students' misconceptions about understanding mathematical concepts on the subject matter of quadratic equations in class X5 SMA Negeri 11 Makassar. MaPan Jurnal Matematika dan Pembelajaran, 3(2), 194-209. https://doi.org/10.24252/mapan.2015v3n2a5.

Septiana, D., Zulfiani, \& Noor, M.F. (2014). Identification of students' misconceptions on the concept of archaebacteria and eubacteria using two-tier multiple coice. Edusains, 6(2). https://doi.org/10.15408/es.v6i2.1151.

Setyadi, E., \& Komalasari, A. (2012). Misconceptions about temperature and heat in grade 1 students of SMA Muhammadiyah Purworejo, Central Java. Berkala Fisika Indonesia, 1(1\&2). http://journal.uad.ac.id/index.php/BFl/article/view/240.

Siswana, R., Armen, \& Helendra. (2017). Identification of misconceptions about photosynthesis material in class IX students of SMPN 7 using a two tier multiple coice diagnostic test. Journal Biosains, 1(2), 277-284. http://ejournal.unp.ac.id/students/index.php/bio/issue/download/355/59.

Sholihat, F.N., Samsudin, A., \& Nugraha, M.G. (2017). Identification of misconceptions and causes of student misconceptions using a four-tier diagnostic test on dynamic fluid sub-material: the principle of continuity. Jurnal Penelitian \& Pengembangan Pendidikan Fisika, 3(2), 175-180. https://doi.org/10.21009/1.03208.

Suparno, P. (2005). Misconceptions and changing concepts in physics education. PT Grasindo.

Suparno, P. (2008). Free experimental method to increase understanding and eliminate misconceptions of students about the concept of thermophysics. Widya dharma majalah ilmiah kependidikan, 9(1).

Syahrul, D.A., \& Setyarsih, W. (2015). Identification of misconceptions and causes of students' misconceptions using a three-tier diagnostic test on the rotation dynamics material. Jurnal Inovasi Pendidikan Fisika, 4(3), 67-70. https://jurnalmahasiswa.unesa.ac.id/index.php/inovasi-pendidikanfisika/article/view/13305/12214.

Umam, A.N., Maharta, N., \& Rosidin, U. (2012). Analysis of students' mastery of physics concepts with concrete thinking and formal thinking skills. Jurnal Pembelajaran Fisika, 1(1), 1-12. http://jurnal.fkip.unila.ac.id/index.php/JPF/article/view/3263.

Wahyudi, I., \& Maharta, N. (2013). Understanding of physics concepts and misconceptions in physics teachers at RSBI High School in Bandar Lampung. Jurnal Pendidikan MIPA, 14(1). http://jurnal.fkip.unila.ac.id/index.php/JPM/article/view/2415.

Wahyuningsih, E. (2016). Identification of the fifth grade students' science misconceptions at Kanisius Beji elementary school for the 2015/2016 academic year. Jurnal Pendidikan Guru Sekolah Dasar.

Widoyoko, E.S. (2009). Evaluation and learning program. Pustaka Pelajar.

Wisudawati, A W., \& Eka, S. (2014). Science learning methodology. Bumi Askara.

Wiyono, F.M., Sugiyanto, \& Yulianti, E. (2016). Identification of the results of the misconception of motion analysis using a three tier diagnostic instrument for junior high school students. Jurnal Pendidikan Fisika dan Aplikasinya, 6(2). https://doi.org/10.26740/jpfa.v6n2.p61-69.

Wulandari, P.I., Mulyani, B., \& Utami, B. (2019). Identification of student misconceptions using a three-tier multiple choice in the redox concept material for class $X$ mipa Batik 1 Surakarta senior high school. Jurnal Pendidikan Kimia, 8(2). https://doi.org/10.20961/jpkim.v8i2.26766. 